\title{
A Probabilistic Tsunami Hazard Assessment for the Makran Subduction Zone at the Northwestern Indian Ocean
}

\author{
Mohammad Heidarzadeh ${ }^{\mathrm{a}, *}$, Andrzej Kijko ${ }^{\mathrm{b}}$ \\ ${ }^{a}$ Faculty of Civil Engineering, College of Engineering, University of Tehran, 11155-4563 \\ Tehran, Iran \\ ${ }^{\mathrm{b}}$ Aon Benfield Natural Hazard Centre, University of Pretoria, Pretoria, South Africa \\ "Corresponding Author: Mohammad Heidarzadeh, Faculty of Civil Engineering, College of \\ Engineering, University of Tehran, Enghelab Ave., Tehran, Iran. P. O. Box: 11155-4563, Tel: (+98) 21 \\ 22900048, Fax: (+98) 21 22222407, Email: heidarz@ut.ac.ir
}

\begin{abstract}
Due to lack of sufficient historical data of tsunami in the Makran subduction zone (MSZ) at the northwestern Indian Ocean, a probabilistic method is employed to assess the tsunami hazards in this region. The method employs a combination of probability evaluation of offshore earthquake occurrence and numerical modeling of tsunami to determine the probability of tsunami wave height exceeding a certain level. The method allowed us to determine the likelihood of tsunami in the region which is a key component of any comprehensive tsunami hazard assessment. In this study, the results of seismic hazard assessment are validated using the previous estimates of the return period of large earthquakes in the MSZ. Also, we validated our numerical modeling of tsunami using historical observations of the Makran tsunami of 1945. It has been observed that the southern coasts of Iran and Pakistan as well as Muscat are the most vulnerable areas in the region to the impact of possible tsunami. The probability of having tsunami waves exceeding $5 \mathrm{~m}$ during the next 50 years in these coasts is $17.5 \%$. In addition, a probability value as high as $45 \%$ during the next 50 years is found for moderate tsunamis along the southern coasts of Iran and Pakistan, as well as southern coast of Oman. Based on the results, the first priority for tsunami hazard mitigation planning in the region should be given to the development of inundation maps for the southern coasts of Iran and Pakistan as well as Muscat. Also, the development of a regional tsunami warning system in the Makran zone is necessary since there is a high probability for moderate tsunami in all Makran coasts.
\end{abstract}

Keywords: Tsunami, Indian Ocean, Makran Subduction Zone (MSZ), Probabilistic Tsunami Hazard Assessment (PTHA), Numerical Modeling

\section{INTRODUCTION}

The 26 December 2004 Sumatra earthquake and tsunami was fresh evidence showing the potential tsunami hazard associated with the large subduction zone earthquakes. This mega-tsunami reminded the international community about the need to assess tsunami hazard for various world's vulnerable coastlines to the impact of tsunami. According to Walker (2005), failure to accurately assess the risks associated with tsunamis in the Indian Ocean, and 
absence of a general understanding of the destructive potential of tsunamis were key elements recognized as contributing factors in the 2004 tragedy.

Although tsunamis are not as common in the Indian Ocean as in the Pacific, Rastogi and Jaiswal (2006) reported about 90 tsunamis in the Indian Ocean. A review of various Indian Ocean and world's tsunami catalogs (Heck, 1947; Berninghausen, 1966; Murty and Rafiq, 1991; Murty and Bapat, 1999) reveals that essentially tsunami in the Indian Ocean basin have been generated by two subduction zones in this region, namely Sunda subduction zone at the east and MSZ at the northwest of this Ocean (Fig. 1).

MSZ at the northwestern Indian Ocean had generated the deadliest tsunami in the Indian Ocean region prior to the 2004 tragedy, i.e. Makran tsunami of 1945 with the death toll of about 4000 people (Heck, 1947). In view of tsunami hazard assessment, Makran remains one of the least studied regions in the Indian Ocean region. Until the present, no tsunami hazard assessment is performed for this subduction zone and thus the level of hazard faced by different Makran coasts is not known. However, Heidarzadeh et al. (2007-a\&b) recently studied historical tsunamis in this region. According to their work, the northwestern Indian Ocean has experienced at least 8 tsunamis (Figure 1), most of which were generated due to the seismicity of the MSZ. Although the provided tsunami list is a major progress towards the understanding of the tsunami hazard in the MSZ, it is necessary to have quantitative estimates of the tsunami hazard for development of reliable risk mitigation strategies.

Since there is very limited historical tsunami data in the MSZ, the assessment of tsunami hazard for this region requires the application of the probabilistic methodology. Here we employ the method of probabilistic tsunami hazard assessment (PTHA) to analyze the Makran tsunami hazard for the first time. In our method, a combination of probability evaluation of offshore earthquake occurrence and numerical modeling of tsunami are employed to determine the probability of having a tsunami whose maximum water elevation exceeds a certain value at a coastal site. To predict possibility of the earthquake occurrence, the doubly truncated Gutenberg-Richter recurrence relationship is employed. Also, a well validated hydrodynamic model is used for numerical modeling of tsunami. 


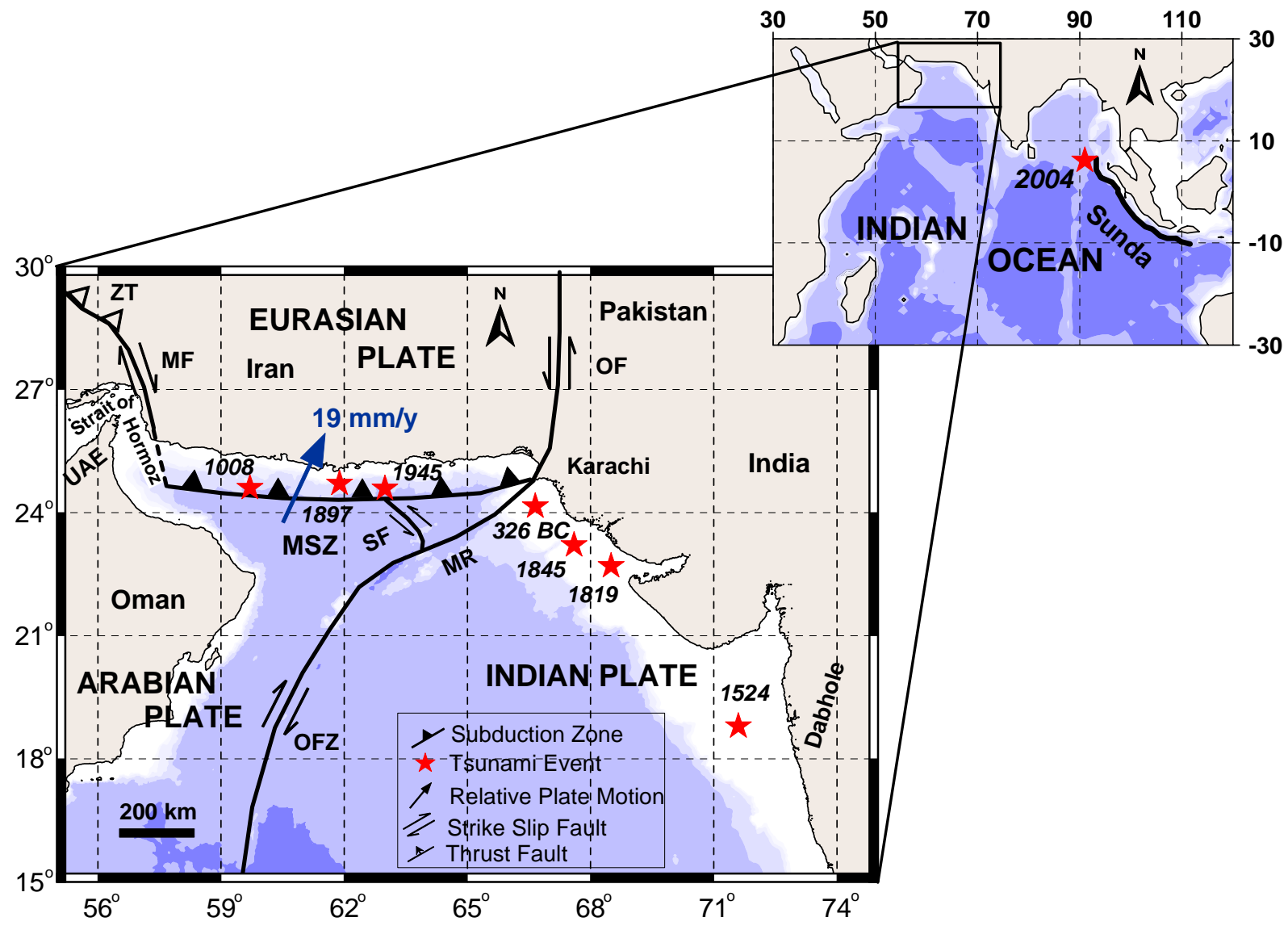

Figure 1. Two main tsunamigenic sources in the Indian Ocean including Sunda subduction zone and Makran subduction zone (top-right) along with tectonic map of the Makran and historical tsunamis (bottom-left). Abbreviations are: Strait of Hormoz (SH), Makran Subduction Zone (MSZ), Zagros Thrust (ZT), Minab-Zendan Fault (M-ZF), Sonne Fault (SF), Murray Ridge (MR), Owen Fracture Zone (OFZ), and Ornach-Nal Fault (O-NF).

\section{TECTONIC SETTING}

MSZ in the northwestern Indian Ocean extends east from the Strait of Hormoz in Iran to near Karachi in Pakistan with the length of about $900 \mathrm{~km}$ (Figure 1). Makran, known as the Indian Ocean's forgotten subduction zone (E. A. Okal, personal communication, 2006), is a relatively recently known subduction zone. For the first time, Stoneley (1974) proposed a subduction zone off the Makran coasts that formed the boundary between the Arabian and Eurasian Plates. Later, Shearman (1977) and Farhoudi and Karig (1977) presented data to support this hypothesis. By conducting a comprehensive study on the Makran's seismicity, Quittmeyer and Jacob (1979) concluded that the seismicity in the Makran region is consistent with the interpretation of this area as an active subduction zone. In addition, Page et al. (1979) by performing a field survey of the Iranian coastline, air photo analysis, and aerial reconnaissance, concluded that the raised beaches along the Makran coast confirm the tectonic model of subduction zone for off the Makran coast.

As shown in Figure 1, the boundaries of the MSZ are rather complex tectonic areas. Major transparessional strike-slip systems, the Ornach-Nal fault systems, form the eastern boundary of the MSZ. The Minab-Zendan fault system forms the western boundary of the MSZ as a 
transition zone between the Zagros continental collision and the Makran Oceanic subduction (Vernant et al., 2004). Also, to the south the Murray ridge delineates part of the Arabian-Indian plate boundary.

Recent studies by employing a network of 27 GPS (Global Position System) stations in Iran and Northern Oman revealed that the subduction rate at the MSZ is about $19.5 \mathrm{mmy}^{-1}$ (Vernant et al., 2004). Compared to the convergence rate of the other world's subduction zones, Makran is a relatively slow moving subduction zone (Heidarzadeh, et al., 2006). Makran has one of the largest accretionary wedges on the earth, and is characterized by an extremely high sediment thickness of $7 \mathrm{~km}$ (Koppa et al., 2000). Unlike the other world's subduction zones, there is no trench at the location of the MSZ (Schluter et al., 2002). As many other world's subduction zones, many active mud volcanoes are present all along the MSZ. Snead (1966) reported that active mud volcanoes have been developed along several of the weak anticlinal axes.

\section{REVIEW OF INTERNATIONAL EFFORTS IN THE FIELD OF PTHA}

Compared to seismic hazard assessment, tsunami hazard analysis is a relatively new science and few studies have been devoted to this subject. In view of engineering purposes, determining the likelihood of a tsunami with certain wave height is a key component of any tsunami mitigation program. This is possible only through PTHA. A review of international efforts in this field reveals that researchers have used two types of PTHA as follows:

a) Modeling based PTHA: Lin and Tung (1982) suggested that tsunami hazard can be calculated following the idea underlying seismic hazard analysis. They combined simple seismological and hydrodynamic models and analyzed tsunami hazard as the probability of the event that the water elevation at a site exceeds an arbitrary but specified level. Despite their hydrodynamic and seismological models were rather simple, the methodology used by Lin and Tung (1982) was novel, and later was employed by several researchers. Rikitake and Aida (1988) used the same methodology but an improved hydrodynamic model to assess the tsunami hazard probability in Japan. However, their numerical modeling of tsunami was stopped at the $200 \mathrm{~m}$ depth contour, and then, they used empirical amplification factors to calculate onshore wave heights. This method also has been applied by some other authors (e.g. Giest and Parsons, 2006; and Annaka et al., 2007).

b) Runup data based PTHA: An alternative approach is to examine the past record of tsunami at individual locations to determine whether a scaling relationship describes the record (Burroughs and Tebbens, 2005). Using runup data from 10 locations in Japan, Burroughs and Tebbens (2005) examined the cumulative frequency-size distributions and determined the scaling relationships and recurrence intervals for runup heights. Orfanogiannaki and Papadopoulos (2007) used the tsunami runup data of three tsunamigenic regions of the Pacific Ocean to present a conditional probability assessment of the tsunami potential. Using data of the runup heights obtained in the field surveys of several tsunamis, Choi et al. (2002) calculated the empirical distribution functions. It is evident that the runup data based PTHA is applicable only when adequate historical information and measurements of tsunami runup are available.

\section{OUR METHODOLOGY FOR THE MAKRAN PTHA}

In the present study, we employ the modeling based PTHA method for the Makran tsunami hazard assessment. The historical data of tsunami in the Makran region are rather poor. Only one tsunami (the 1945 event) is instrumentally recorded in this region. However, no tide gauge data is available for this event, and the distribution of tsunami wave heights along different Makran coasts are not well recorded. Therefore, it is clear that the method of runup data based PTHA cannot yield useful results, and thus we employ the modeling-based method. 
Our method is similar to that of Rikitake and Aida (1988) with some improvements in hydrodynamic and seismological models. In contrast to the work of Rikitake and Aida (1988), we employ a well-validated hydrodynamic model. Also, we modify the Rikitake and Aida's (1988) approach by considering a doubly truncated Gutenberg-Richter recurrence relationship for seismic hazard estimation. The method used here includes the following three steps:

(1) Probabilistic forecast of seismic hazard.

(2) Numerical modeling of tsunami.

(3) Probabilistic tsunami hazard assessment.

Specifics of each step will be given in the sections to follow.

\section{PROBABILISTIC FORECAST OF SEISMIC HAZARD AND VALIDATION}

As the occurrence of a large earthquake in offshore region is necessary for tsunami generation, the first step in the modeling-based PTHA is to evaluate the probability of offshore earthquake occurrence. For predicting possibility of the earthquake occurrence, the most common treatment assumes that the frequency of seismic events follow the Gutenberg-Richter (GR) relation. This relation is:

$\log _{10} N=a-b M$

where $N$ is the cumulative total number of earthquakes with magnitude equal to or greater than $M$ that occur in a given region, and $a$ and $b$ are constant parameters that depend on the region.

The area surveyed for assessing the seismicity comprised a rectangle limited between $23^{\circ}$ to $28^{\circ} \mathrm{N}$, and $57^{\circ}$ to $70^{\circ} \mathrm{E}$. A variety of sources was used to compile an earthquake catalog for the MSZ which can be classified as belonging to one of two categories: historical (noninstrumental) or modern (instrumental). All data concerning events prior to 1900 are of historical type. Modern data consist of hypocenters and instrumentally recorded arrival times from worldwide stations that are reported in various catalogs, books and journals. The epicenters and magnitudes of the compiled earthquakes are shown in Figure 2. The catalog of Makran historical and instrumental large earthquakes with magnitude greater than or equal to 6.5 is presented in Table 1 . According to Table 1, the maximum observed earthquake in the region is the event of the November 27, 1945 with the moment magnitude of 8.1. Figure 3 presents the G-R relation for the MSZ.

The probabilistic forecast of seismic hazard in this study was performed by making use of the Kijko-Sellevoll's method (Kijko \& Sellevoll, 1989; Kijko \& Sellevoll, 1992) which uses a doubly truncated Gutenberg-Richter equation. Assuming the Poisson occurrence of earthquakes with an activity rate $\lambda$, the density and cumulative magnitude distributions of the earthquakes in the form of the doubly truncated Gutenberg-Richter magnitude-frequency relation can be written respectively as follows (Kijko \& Sellevoll, 1992):

$$
\begin{array}{ll}
f(x \mid m)=\beta A(x) /\left(A_{1}-A_{2}\right) & m_{\text {min }}<x \leq m_{\text {max }} \\
F(x \mid m)=\operatorname{Pr}(X \leq x)=\left[A_{1}-A(x)\right] /\left(A_{1}-A_{2}\right) & m_{\text {min }}<x \leq m_{\text {max }}
\end{array}
$$

where $A_{1}=\exp \left(-\beta m_{\min }\right), A_{2}=\exp \left(-\beta m_{\max }\right), A(x)=\exp (-\beta x)$, and magnitude $x$ belongs to the domain $\left(m_{\min }, m_{\max }\right), m_{\max }$ is the maximum regional magnitude, and $m_{\min }$ is the threshold magnitude. $\beta$ is related to Gutenberg-Richter parameter $\mathrm{b}$ through the relation $\beta=b \operatorname{Ln}(10)$. Kijko and Sellevoll (1989) showed that the maximum regional magnitude, $m_{\max }$, can be obtained using the following equation: 
$m_{\max }=m_{\max }^{o b s}+\frac{E_{1}\left(n_{2}\right)-E_{1}\left(n_{1}\right)}{\beta \exp \left(-n_{2}\right)}+m_{\min } \exp (-n)$

where $m_{\max }^{o b s}$ is the maximum observed magnitude ( $M_{w} 8.1$ for the Makran region), $n$ is the number of all recorded magnitudes, $n_{1}=n /\left\{1-\exp \left[-\beta\left(m_{\max }-m_{\min }\right)\right]\right\}$, $n_{2}=n_{1} \exp \left[-\beta\left(m_{\max }-m_{\min }\right)\right]$, and $E_{1}($.$) denotes an exponential integral function. E_{1}($.$) is$ defined as $E_{1}(z)=\int_{z}^{\infty} \exp (-\xi) / \xi d \xi$.

The Kijko-Sellevoll's procedure permits the combination of both historical and instrumental data. The historical part of the catalogue only contains the strongest events, whereas the complete part can be divided into several sub-catalogues, each assumed complete above a specified threshold of magnitude. The method can also consider gaps when records in the catalogue are missing, and uncertainties in earthquake magnitudes.

Here, we divided the catalog of Makran earthquakes compiled from the above sources into 4 parts. The first part contains historical large events (non-instrumental events). The other three parts are complete catalogs including instrumental data each having certain threshold magnitude and standard deviation. The results of seismic hazard assessment for the MSZ are shown in Figure 4. Estimates of the earthquake return periods in the MSZ are shown in Fig. 4-a. Also, Fig. 4-b presents the probability of earthquakes with certain magnitudes in the next $1,50,100$ and 1000 years. For example, based on Figure 4, the return period of an $M_{w} 8.1$ earthquake is about 250 years in the MSZ, and the probability of having such an earthquake in the next 50 years is about $17.5 \%$ in this region.

To validate the results of the seismic hazard assessment, we compare our results with the previous estimates of the return period of large earthquakes in the MSZ. Byrne et al. (1992) believed that if all of the plate motion between Eurasia and Arabia occurred during earthquakes like the 1945 event $\left(M_{w} 8.1\right)$, such events would be expected to repeat about every 175 to 300 years in eastern Makran. By calculating the average uplift rate along the Makran coast, Page et al. (1979) estimated that the recurrence of a 1945-type earthquake along the MSZ is approximately 125 to 250 years. Our results presented in Figure 4-a suggest a return period of about 250 years for a 1945-type earthquake $\left(M_{w} 8.1\right)$ which is in agreement with the previous estimates made by Page et al. (1979) and Byrne et al. (1992).

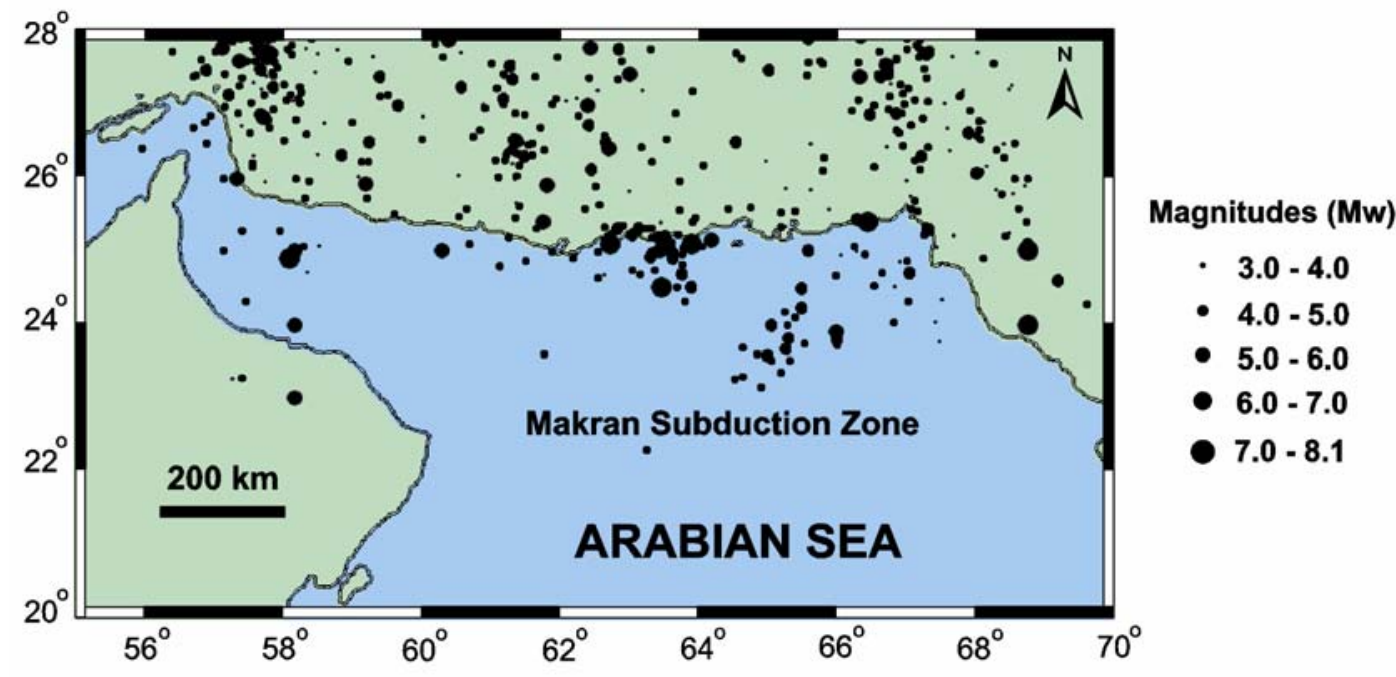

Figure 2. The epicenters and magnitudes of earthquakes in the Makran region. 
Table 1. Catalog of Makran historical and instrumental great earthquakes (Magnitude $\geq 6.5)$

\begin{tabular}{|c|c|c|c|c|c|c|c|c|}
\hline No. & $\begin{array}{c}\text { Date } \\
\text { (yy-mm-dd) }\end{array}$ & $\begin{array}{l}\text { Latitude } \\
\text { (degree) }\end{array}$ & $\begin{array}{l}\text { Longitude } \\
\text { (degree) }\end{array}$ & $\begin{array}{c}\text { Focal } \\
\text { Depth } \\
(\mathbf{k m})\end{array}$ & Ms" & Mw** & $\begin{array}{l}\text { Intensity } \\
(\mathrm{MM})^{\dagger}\end{array}$ & References ${ }^{\dagger \dagger}$ \\
\hline 1 & 326 BC & $24.00 \mathrm{~N}$ & $67.30 \mathrm{E}$ & & \multicolumn{3}{|c|}{$\begin{array}{l}\text { Strong tsunami was } \\
\text { produced }\end{array}$} & $1,2,3,4$ \\
\hline 2 & $1008-5$ & $\begin{array}{l}25.00 \\
(27.7)^{\perp}\end{array}$ & $\begin{array}{l}60.00 \\
(52.3)\end{array}$ & & & & $8-9$ & $2,3,4,5,6$ \\
\hline 3 & $1483-2-18$ & 24.90 & 57.90 & & & & 10 & $5,7,8$ \\
\hline 4 & $1668-5$ & 25.00 & 68.00 & & & & $8-9$ & $7,9,10$ \\
\hline 5 & $1688-5$ & 24.00 & 68.00 & & & & $8-9$ & $7,9,10$ \\
\hline 6 & 1765 & 25.40 & 65.80 & & & & $8-9$ & 8,11 \\
\hline 7 & 1849 & 27.70 & 57.60 & & & & $8-9$ & 5,7 \\
\hline 8 & 1851-4-19 & 25.10 & 62.30 & & & & $8-9$ & $5,8,10,12,17$ \\
\hline 9 & 1927-07-07 & 27.00 & 62.00 & & 6.5 & & & 5,13 \\
\hline 10 & 1929-09-03 & 26.40 & 62.30 & & 6.5 & & & 5,13 \\
\hline 11 & $1934-06-13$ & 27.43 & 62.59 & 35.0 & 7.0 & & & 5,13 \\
\hline 12 & $1945-11-27$ & 24.50 & 63.00 & 25.0 & \multicolumn{3}{|c|}{8.1} & $\begin{array}{l}1,2,3,4,5,6,7,8,10,13 \\
14,16,17\end{array}$ \\
\hline 13 & 1947-08-05 & 25.10 & 63.40 & 35.0 & 7.6 & & & $5,7,8,13$ \\
\hline 14 & $1948-1-30$ & 25.14 & 63.69 & 30.0 & 6.5 & & & 13,9 \\
\hline 15 & $1962-12-26$ & 23.90 & 65.40 & & 6.5 & & & 13,9 \\
\hline 16 & $1964-12-22$ & 27.80 & 57.00 & & 6.5 & & & 13,9 \\
\hline 17 & 1969-11-07 & 27.90 & 60.10 & 35.0 & 6.5 & & & 5,13 \\
\hline 18 & 1972-08-06 & 25.40 & 61.40 & & 7.0 & & & $13,15,9$ \\
\hline 19 & $1974-12-02$ & 24.00 & 58.00 & & 6.5 & & & $13,9,15$ \\
\hline 20 & 1979-01-10 & 26.52 & 61.01 & & 6.7 & & & $13,9,15$ \\
\hline 21 & $1980-11-28$ & 23.00 & 58.00 & & 7.0 & & & $13,9,15$ \\
\hline 22 & $1983-04-18$ & 27.79 & 62.05 & 64.0 & & 7.0 & & $9,13,15$ \\
\hline 23 & 1990-06-17 & 27.40 & 65.72 & 14.0 & 7.0 & & & $13,15,9$ \\
\hline
\end{tabular}

*Surface Wave Magnitude, ${ }^{* *}$ Moment Magnitude, $\quad{ }^{\dagger}$ Modified Mercalli,

${ }^{\perp}$ Reported by Ambraseys and Melville, 1982

${ }^{\dagger \dagger}$ (1): Murty and Rafiq, 1991; (2) Murty and Bapat, 1999; (3) Carayannis, 2006; (4) Dominey-Howes et al., 2006; (5) Ambraseys and Melville, 1982; (6) Rastogi and Jaiswal, 2006; (7) NOAA, 2007; (8) Byrne et al., 1992; (9) USGS, 2007; (10) Quittmeyer and Jacob,1979; (11) Walton, 1864; (12) Merewether, 1852; (13) ISC, 2007; (14) Pendse, 1946; (15) Harvard Seismology, 2007; (16) Heck, 1947; (17) Okal et al. (2006) 


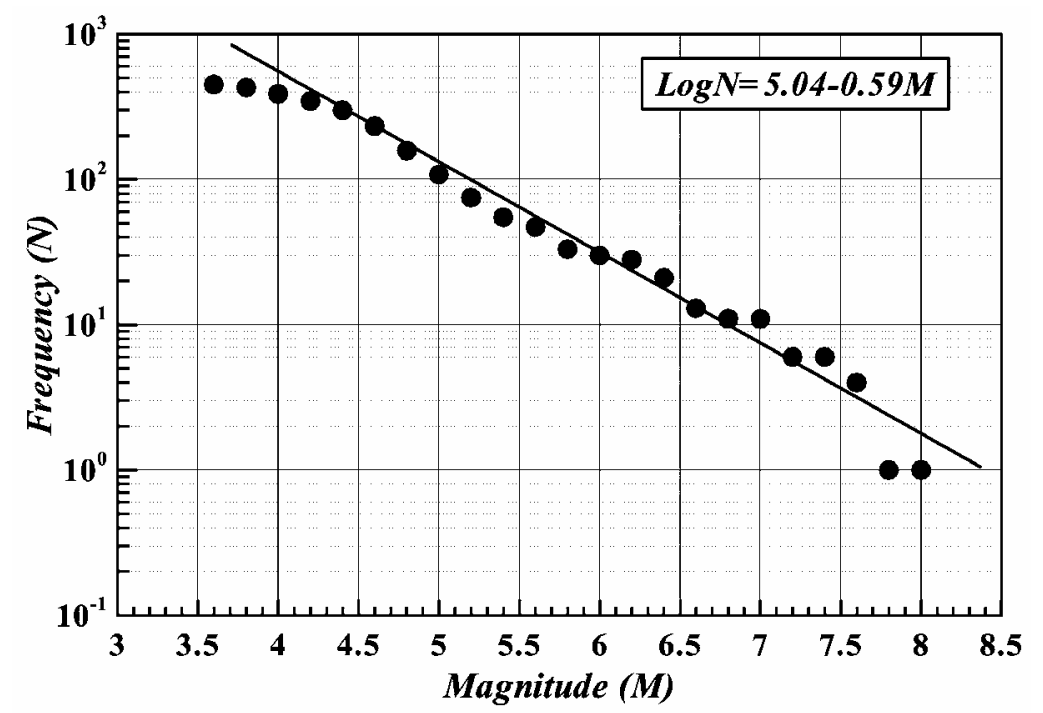

Figure 3. The G-R relation for the seismicity of the MSZ.

(a)

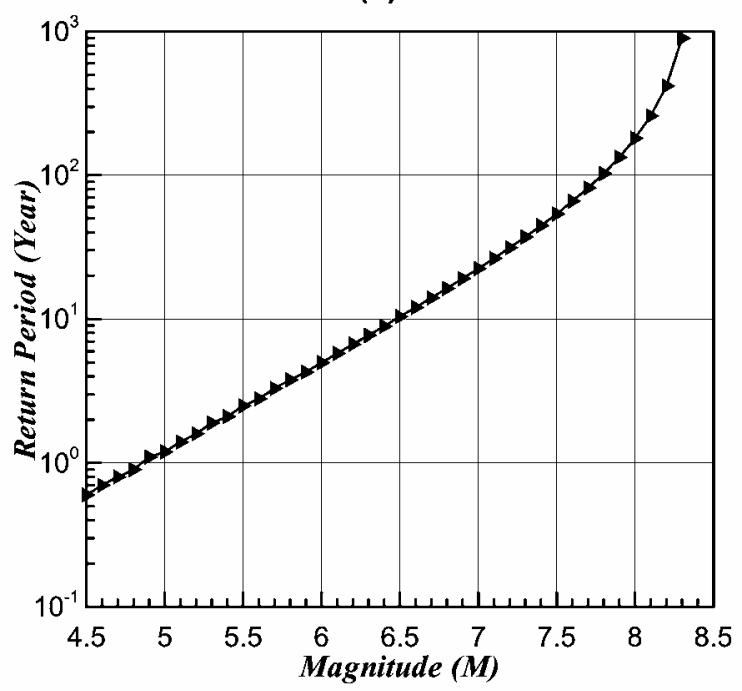

(b)

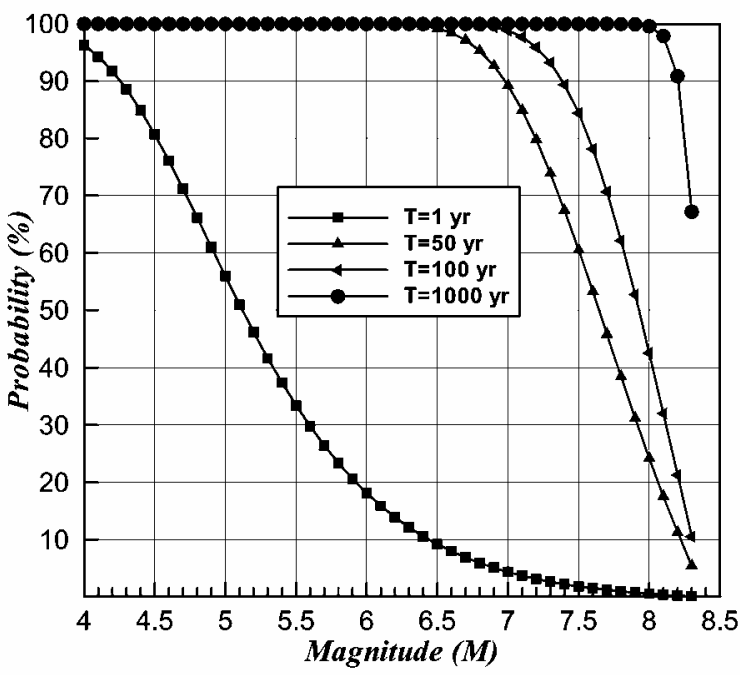

Figure 4. Estimation of the earthquake return periods in the Makran region (a), and the probability of earthquakes with certain magnitudes in the next 1, 50, 100 and 100 years

(b).

\section{NUMERICAL MODELING OF TSUNAMI AND VALIDATION}

The numerical model TUNAMI-N2 is used for simulation of propagation and coastal amplification of long waves. The model was originally authored by Professors Nobuo Shuto and Fumihiko Imamura of the Disaster Control Research Center in Tohoku University (Japan) through the Tsunami Inundation Modeling Exchange (TIME) program (Goto et al., 1997). TUNAMI-N2 is one of the key tools for developing studies for propagation and coastal amplification of tsunamis in relation to different initial conditions. It solves nonlinear shallow water equations in Cartesian coordinates using a leap-frog scheme in finite difference technique 
for basins of irregular shape and topography (Yalciner et. al., 2002 and 2004). The model and its application procedures are described in detail in the IOC manual number 35 (Goto et al., 1997). Also, a similar methodology is used in the numerical model MOST (Method of Splitting Tsunami) developed by Titov and Synolakis (Titov and Synolakis, 1997; Titov and Synolakis, 1998; Synolakis, 2003). TUNAMI-N2 and MOST are the only two existing nonlinear shallow water codes validated with laboratory and field data (Yeh at al., 1996).

Here, we model the 1945 Makran tsunami, the only instrumentally recorded tsunami in the MSZ, in order to validate the result of our tsunami modeling practice using historical observations of this actual tsunami. For modeling seafloor deformation due to the earthquake, the seismic parameters of the 1945 Makran tsunami ( $M w$ 8.1) estimated in the study by Byrne et al. (1992) are used, which produce $2 \mathrm{~m}$ uplift on the seafloor. This amount of uplift is in agreement with the observed uplift during the 1945 event according to Page et al. (1979). The total number of grid points in the computational domain is 369852 which is $833 \times 444$ points. The time step is selected as $1.0 \mathrm{~s}$ to satisfy the stability condition. The duration time of wave propagation is $5 \mathrm{~h}$ in our simulations. Figure 5 shows examples of snapshots of the water surface displacement at times $t=15,30,45$, and 60 minutes. In addition, Figure 6 presents the distribution of the 1945 tsunami wave heights along different coastlines.

The data of Makran 1945 tsunami wave heights on the coastlines are rather poor and no tide gauge data is available. However, we were able to collect some data about tsunami wave heights on various Makran coasts. According to Ambraseys and Melville (1982), tsunami wave height in Pasni was about 4 to $5 \mathrm{~m}$, and was about 1.5 meter high in Karachi. Also, they reported the tsunami was observed along Makran coasts of Iran and Oman. However, no damage and loss of life were reported from these coastlines.

According to Figure 6, the distribution of tsunami wave height along various Makran coasts reproduces most feathers of the historical observations during the 1945 event. Our numerical model successfully reproduces the wave height of 4 to $5 \mathrm{~m}$ at Pasni as well as $1.5 \mathrm{~m}$ in Karachi. In addition, Figure 6 shows that the simulated wave heights at the southern coast of Iran and northern coast of Oman are less than $1 \mathrm{~m}$, thus it is reasonable that there is little information about the effects of the Makran tsunami of 1945 in these coasts.
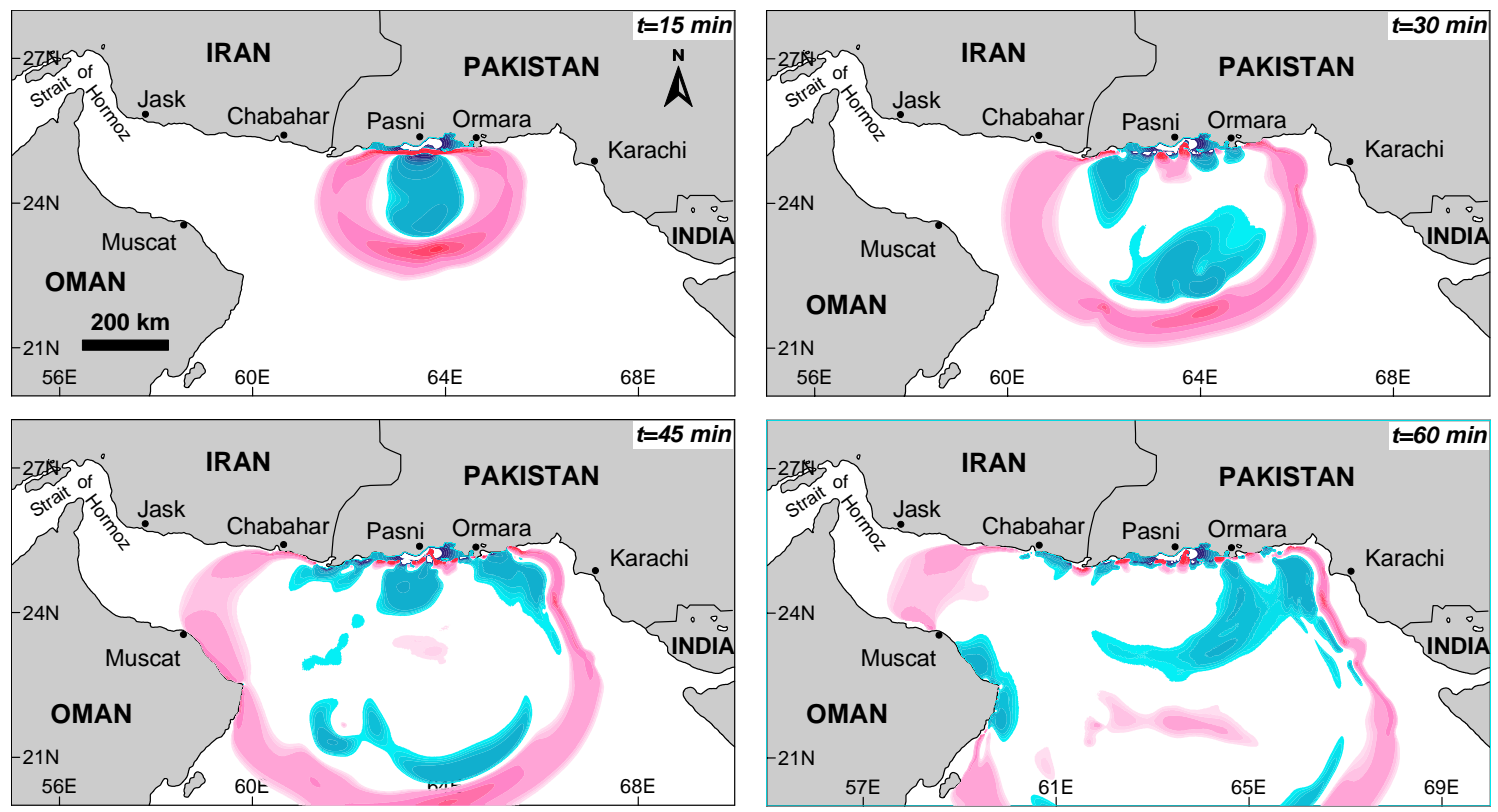

Figure 5. Snapshots of the tsunami simulation at time $t=15,30,45$ and $60 \mathrm{~min}$ due to the Makran tsunami of 1945. 


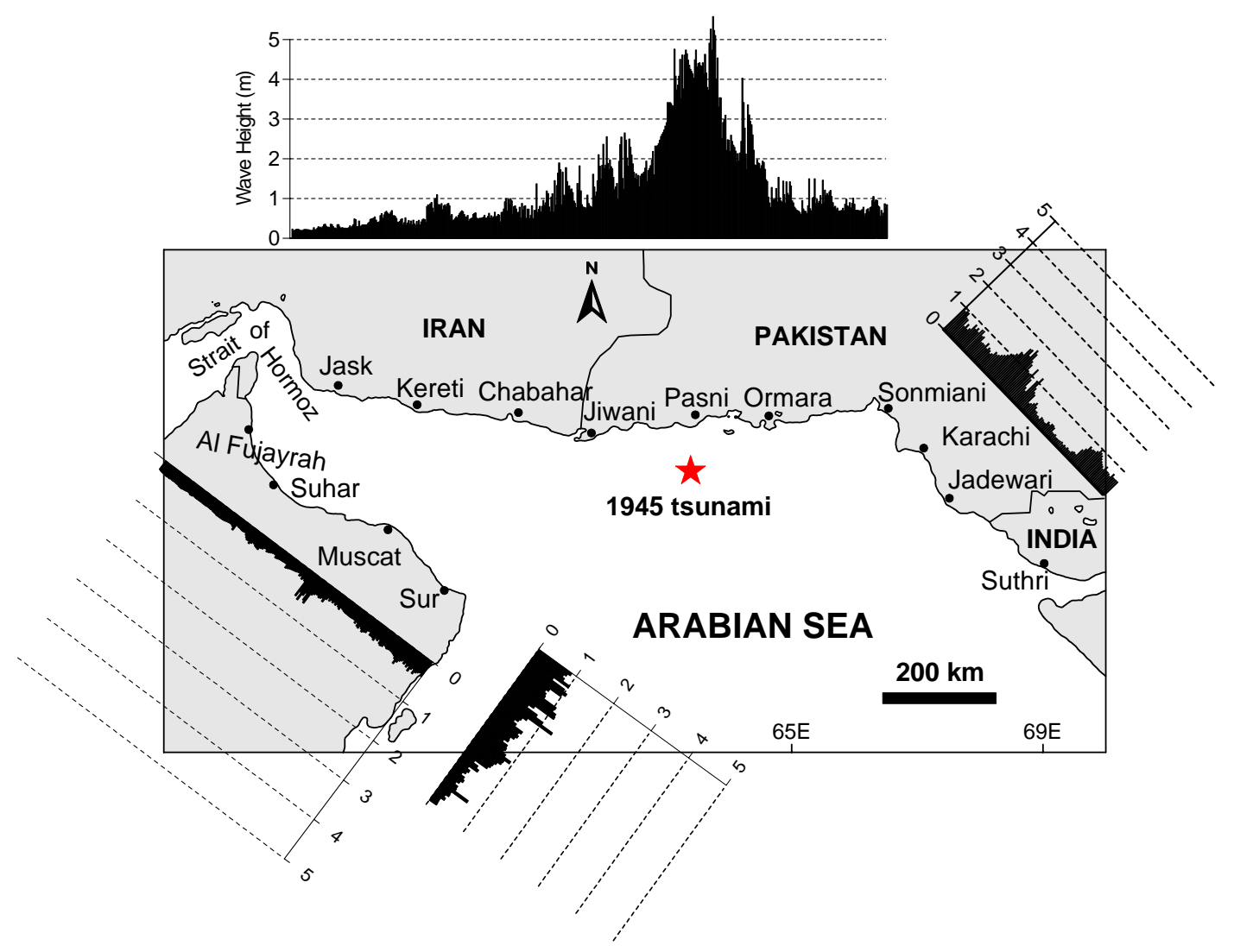

Figure 6. Distribution of maximum positive tsunami wave heights in various Makran coasts due to the Makran tsunami of 1945.

\section{PROBABILISTIC TSUNAMI HAZARD ASSESSMENT AND RESULTS}

The probabilistic tsunami risk in this study is estimated by a combination of probability evaluation of offshore earthquake occurrence and numerical modeling of the resulting tsunami. Based on this method, the probability of having a tsunami with particular wave height in a selected coastline will be calculated using the following equation which is modified from Rikitake and Aida (1988):

$$
P_{t s u}\left(C_{k}, Z_{i}, h_{c r}, M, T\right)= \begin{cases}P_{e q}\left(Z_{i}, M, T\right) & h_{\max }\left(C_{k}\right) \geq h_{c r} \\ 0 & h_{\max }\left(C_{k}\right)<h_{c r}\end{cases}
$$

where $P_{t s u}\left(C_{k}, Z_{i}, h_{c r}, M, T\right)$ is the probability of tsunami whose wave height exceeds a certain level $\left(h_{c r}\right)$ at a selected $k$ th coastline $\left(C_{k}\right)$ due to an earthquake with magnitude $M$ in the $i$ th tsunamigenic zone $\left(Z_{i}\right)$ in the time interval of $T$ years. $h_{\max }\left(C_{k}\right)$ is the maximum tsunami wave height in the selected $k$ th coastline $\left(C_{k}\right)$. Also, $P_{e q}(Z i, M, T)$ is the probability of an earthquake with magnitude $M$ in the $i$ th tsunamigenic zone $\left(Z_{i}\right)$ in the time interval of $T$ years. For example, according to the seismic hazard assessment, the probability of having a 1945-type earthquake (Mw8.1) in the next 50 years is about 17.5\%. According to Figure 6, such 
an earthquake produces wave heights of about $5.5 \mathrm{~m}$ and $1 \mathrm{~m}$ in Pasni and Chabahar respectively. Therefore, the probabilities for Pasni being hit by tsunami waves having wave heights equal to or larger than $1,3,5$, and $7 \mathrm{~m}$ are evaluated as $0.175,0.175,0.175$, and 0 respectively for a 50 year period. The respective probabilities for Chabahar are $0.175,0,0$, and 0 respectively.

Using equation 10, the total tsunami probability in any selected coastline will be calculated by considering all tsunami-generating sources in the region according to equation 11 (Rikitake and Aida, 1988):

$$
P_{t s u}^{T}\left(C_{k}, Z_{i}, h_{c r}, M, T\right)=1-\prod_{i=1}^{n}\left[1-P_{t s u}\left(C_{k}, Z_{i}, h_{c r}, M, T\right)\right]
$$

where $n$ is the total number of tsunami-generating sources, and $P_{t s u}^{T}\left(C_{k}, Z_{i}, h_{c r}, M, T\right)$ is the total tsunami probability.

Based on the locations of the previous tsunamis generated in the MSZ (Fig. 1), we divide the entire Makran into three tsunami-generating sub-regions including eastern Makran, middle Makran, and western Makran named as Z1, Z2, and Z3 respectively (Fig 7). The data of tsunamigenic earthquakes in the region are rather poor, and the magnitude of the parent earthquakes is known only for one event which is the tsunami of 1945 with moment magnitude of 8.1. Hence, it is impossible to determine the average magnitude of tsunami-generating earthquakes in each of the above sub-regions from historical data. Therefore, the magnitude of tsunami-generating earthquake is assumed to be 8.1 in all three zones, similar to the magnitude of the 1945 event. The distribution of tsunami wave heights from these sources along various Makran coasts can then be calculated in a way similar to the last section. For example, the result of numerical modeling of tsunami for an earthquake in the $\mathrm{Z} 1$ is shown in Figure 8.

As an example, by applying equation 11 to the probabilities of earthquake occurrence in Jiwani, the probabilities of tsunami wave exceeding certain heights are evaluated in Table 2. Similar probability evaluations are made for different coastlines in the Makran region as shown in Figures 9, 10, 11, and 12. These Figures show that the Northern coast of Makran, i.e. the southern coasts of Iran and Pakistan, experience the largest tsunami waves. It is observed from these figures that the highest probability of tsunami wave having a height of $5 \mathrm{~m}$ or larger is expected for the southern coasts of Iran and Pakistan. Most shorelines along these coasts are characterized by a probability of 17.5 percent for tsunami waves exceeding $3 \mathrm{~m}$ during the next 50 years (Figure 9). In northern Oman where the probability of tsunami waves exceeding $5 \mathrm{~m}$ is zero for approximately the entire coast, Muscat experiences relatively huge tsunami amplitude of larger than $5 \mathrm{~m}$ resulting in 17.5 percent probability during the next 50 years (Figure 11). It therefore can be concluded that the worst sites for a highly dangerous tsunami are located on the southern coasts of Iran and Pakistan as well as Muscat. Similar wave amplification can be observed in Karachi although the maximum wave amplitude is about $2 \mathrm{~m}$ (Figure 10). While the probabilities of waves exceeding 1 and $2 \mathrm{~m}$ are zero for many adjacent cities, such probabilities are about 32 and 18 percent respectively in Karachi.

Figure 10 reveals that the probability of tsunami wave height exceeding $1 \mathrm{~m}$ in western coasts of India is zero. It can be attributed to the extended shallow water of this region (Figure 7) which strongly dissipates the energy and wave height of tsunami. According to Figures 9-12, the highest probability for moderate tsunamis $(1 \leq h<2 m)$ is expected again from southern coasts of Iran and Pakistan (Figure 9), as well as southern coasts of Oman (Figure 12) with a probability of about 45 percent during the next 50 years. It is clear from these Figures that there is a high probability for moderate tsunamis in all Makran coasts which emphasizes that the development of a regional tsunami warning system in the MSZ is necessary. 


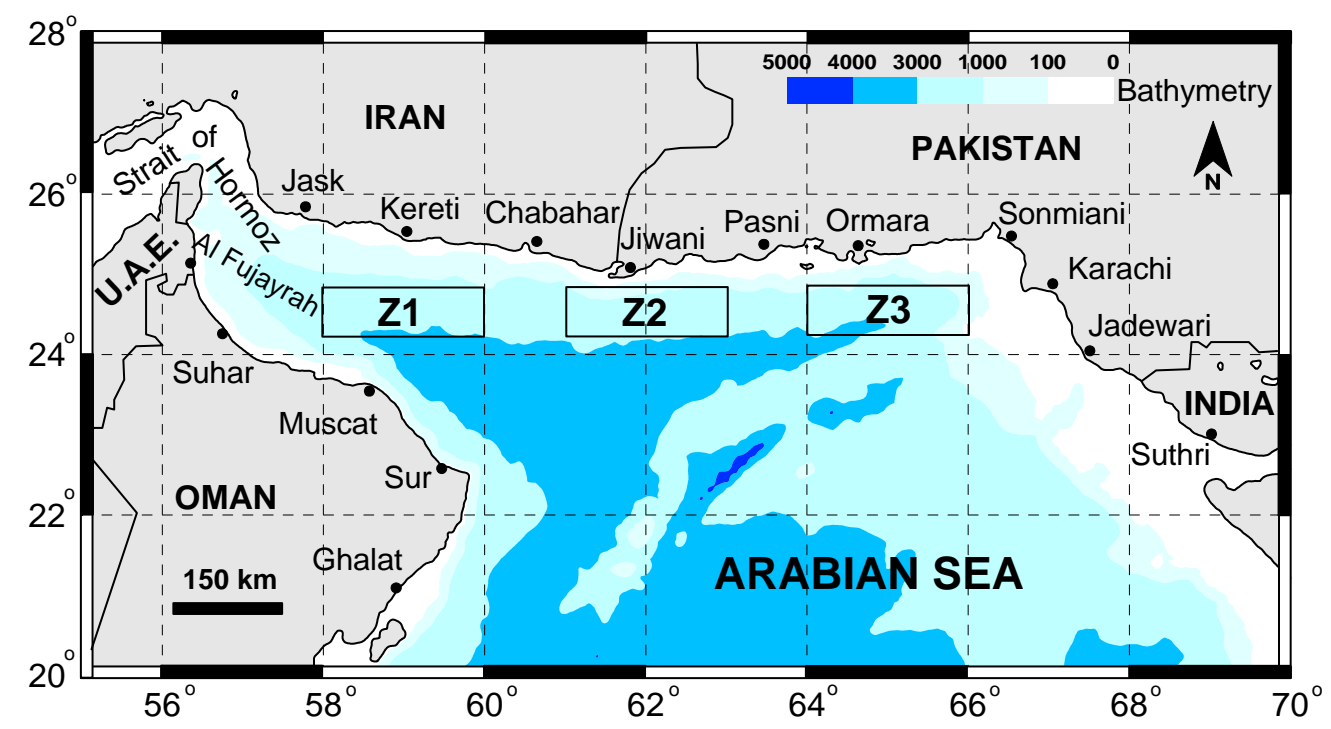

Figure 7. Three tsunamigenic sub-regions in the MSZ used in this study for PTHA.

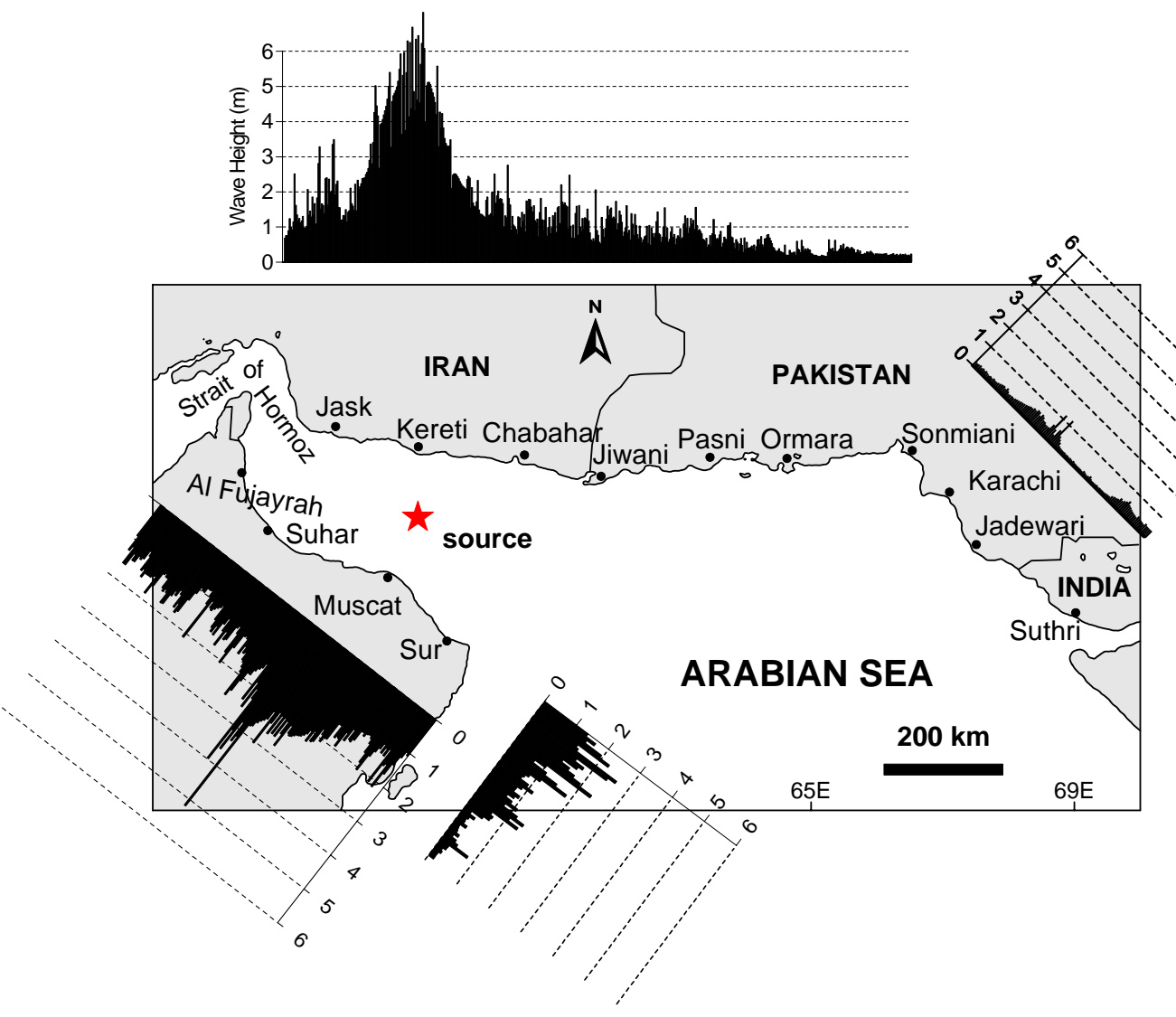

Figure 8. Distribution of maximum positive tsunami wave heights along various Makran coasts for the case of an earthquake in the $Z_{1}$ zone. 
Table 2. Probabilities of tsunami wave exceeding the key heights at Jiwani in the next 50 years

\begin{tabular}{cc}
\hline $\begin{array}{c}\text { Tsunami Wave } \\
\text { Heights (m) }\end{array}$ & Probability (\%) \\
\hline$\geq 1$ & 43.85 \\
\hline 3 & 17.5 \\
\hline$\geq 5$ & 17.5 \\
\hline$\geq 7$ & 0 \\
\hline
\end{tabular}

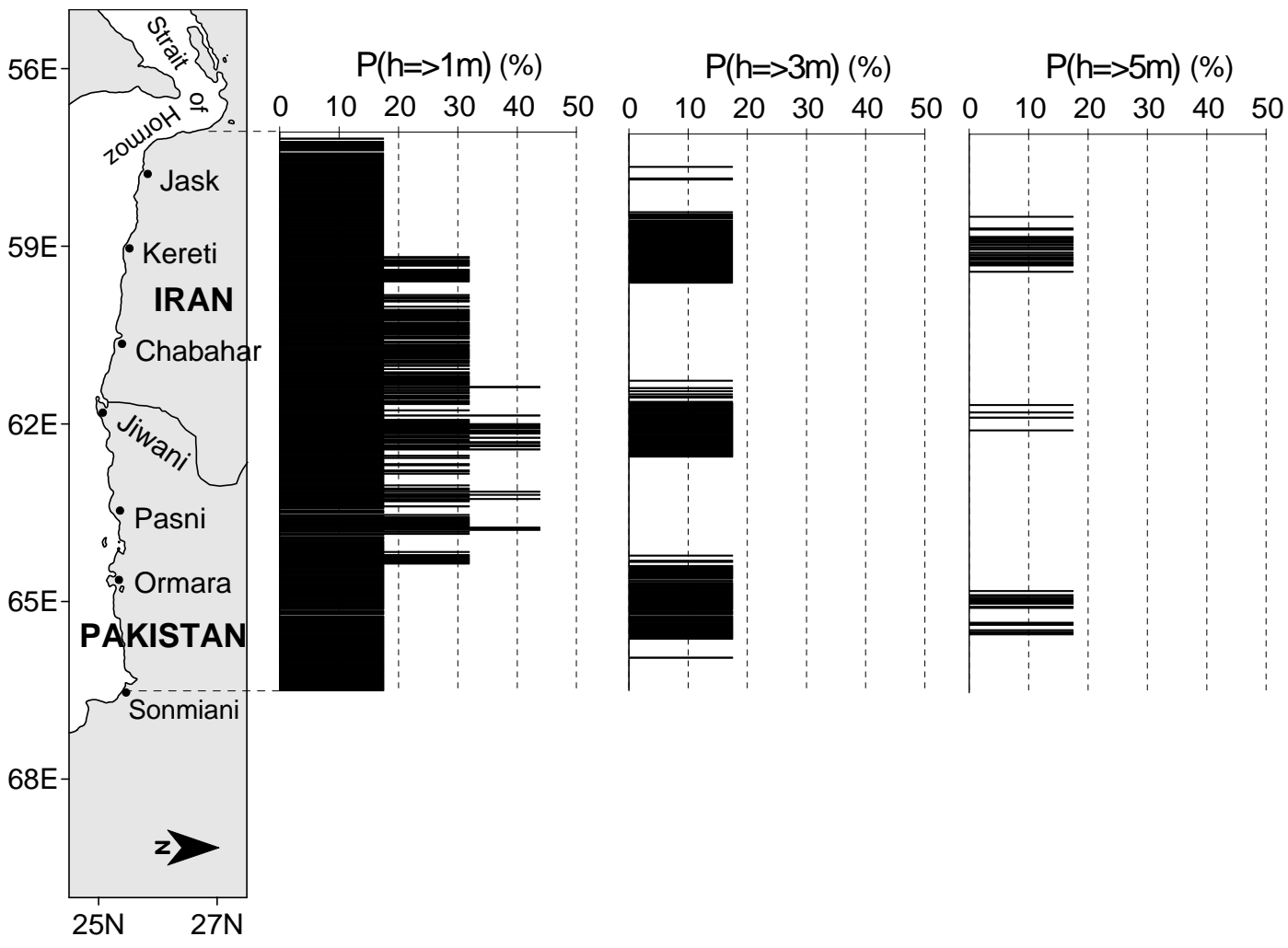

Figure 9. Probabilities for the southern coasts of Iran and Pakistan being hit by a tsunami of which the wave height exceeds 1,3 , and $5 \mathrm{~m}$ in the next 50 years. 


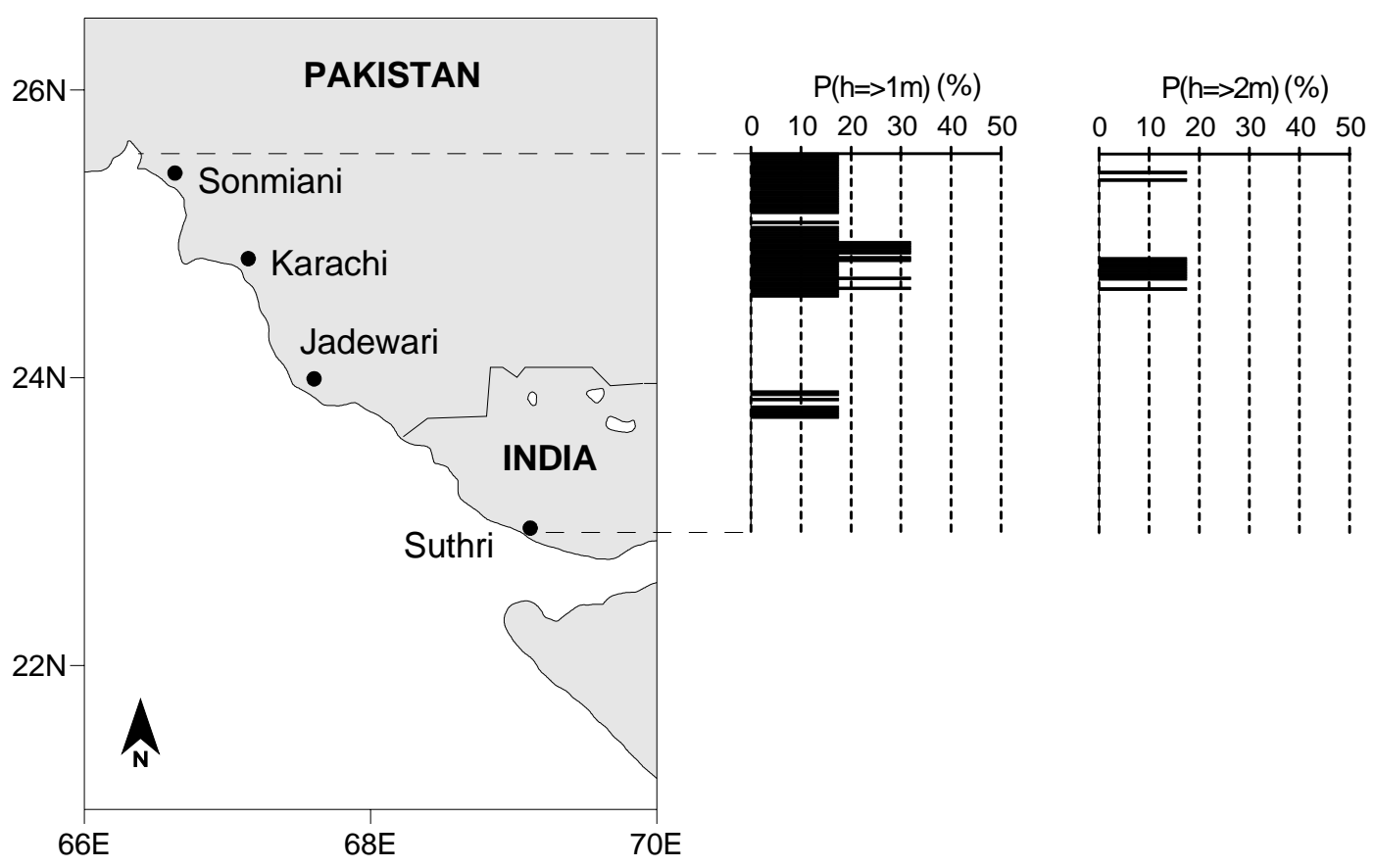

Figure 10. Probabilities for the eastern Makran being hit by a tsunami of which the wave height exceeds 1 , and $2 \mathrm{~m}$ in the next 50 years.

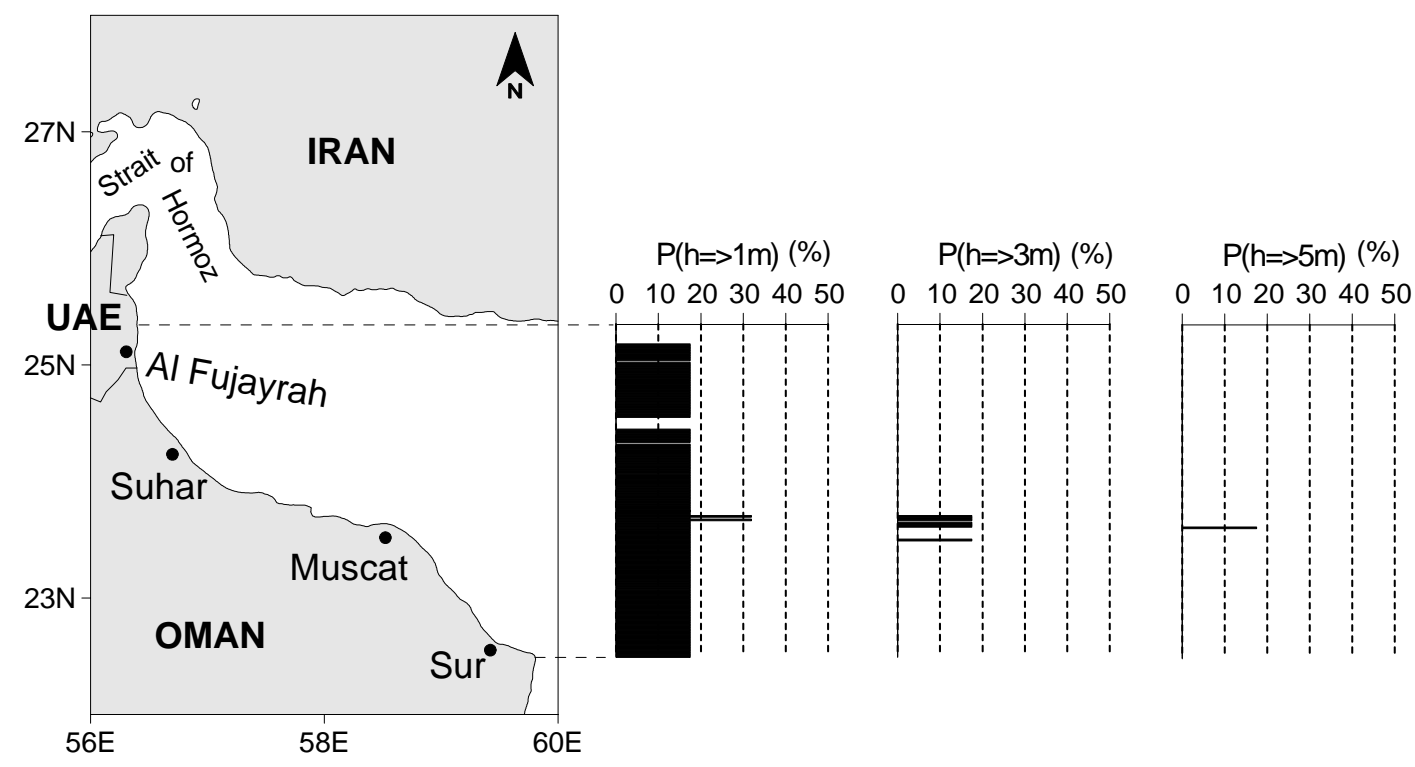

Figure 11. Probabilities for the northern coasts of Oman and eastern coasts of UAE being hit by a tsunami of which the wave height exceeds 1 , and $3 \mathrm{~m}$ in the next 50 years. 


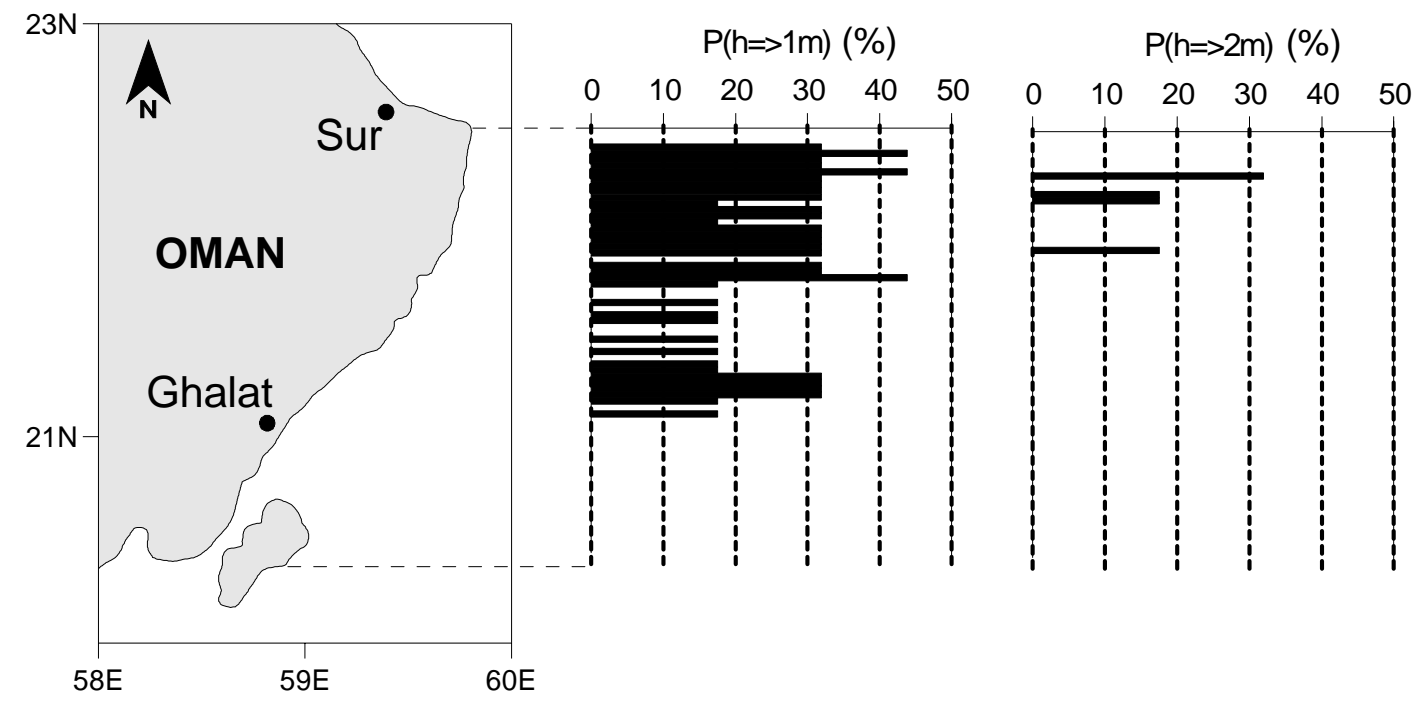

Figure 12. Probabilities for the southern coasts of Oman being hit by a tsunami of which the wave height exceeds 1 , and $2 \mathrm{~m}$ in the next 50 years.

\section{CONCLUSION}

Due to lack of any tsunami hazard assessment for the coastal areas of the MSZ, a probabilistic method was employed to give first generation of tsunami hazard assessment for the region. The main findings of this research are:

1- The seismic hazard assessment reveals that the repeat time of a 1945-type earthquake $\left(M_{w}\right.$ 8.1) in the region is about 250 years which reinforces previous estimates made by Byrne et al. (1992) and Page et al. (1979). The probability of having such an earthquake in the next 50 years is about $17.5 \%$ in this region.

2- It has been observed that the southern coasts of Iran and Pakistan are the most vulnerable coastlines in the region to the impact of tsunami, and experience wave heights larger than $5 \mathrm{~m}$ in the case of a 1945-type tsunamigenic earthquake. The probability of having tsunami waves exceeding $5 \mathrm{~m}$ during the next 50 years in these coasts is $17.5 \%$.

3- Apart from the southern coasts of Iran and Pakistan, results show that a wave height exceeding $5 \mathrm{~m}$ is expected in Muscat with the occurrence probability of $17.5 \%$ for the next 50 years. Strong wave amplification is evident in Muscat.

4- The highest probability for moderate tsunamis $(1 \leq h<2 m)$ is expected from southern coasts of Iran and Pakistan, as well as the southern coast of Oman with a probability of about 45 percent during the next 50 years.

5- Tsunami wave amplification has been observed in Karachi, a very populated coastal city in the region. While the probabilities of waves exceeding 1 and $2 \mathrm{~m}$ are zero for many adjacent cities, such probabilities are about 32 and 18 percent respectively in Karachi.

Based on the results, the first priority for tsunami hazard mitigation planning in the region should be given to the development of inundation maps for the southern coasts of Iran and Pakistan as well as Muscat. Also, the development of a regional tsunami warning system in the Makran zone is necessary since there is a high probability for moderate tsunamis in all Makran coasts.

\section{ACKNOWLEDGEMENT}


The financial support from College of Engineering of the University of Tehran is acknowledged. The long wave propagation model, TUNAMI-N2, used in this study is a registered copyright of Professors F. Imamura, Ahmet C. Yalciner and C. E. Synolakis. The Intergovernmental Oceanographic Commission (IOC) of UNESCO is thanked for providing the funds provided to the first author to participate in the first international tsunami modeling course held in Kuala Lumpur, Malaysia in May 2006. Also, the first author would like to extend his sincere gratitude to Professors Emile A. Okal, Costas E. Synolakis, and Ahmet C. Yalciner for their precious lectures and discussions during the Malaysia course.

\section{REFERENCES}

Ambraseys, N. N., Melville, C. P., 1982. A History of Persian Earthquakes. Cambridge University Press, Britain.

Annaka, T., Satake, K., Sakakiyama, T., Yanagisawa, K., Shuto, N., 2007. Logic-tree approach for probabilistic tsunami hazard analysis and its applications to the Japanese coasts. Pure Appl. Geophys. 164, 577-592.

Berninghausen, W.H., 1966. Tsunamis and seismic seiches reported from regions adjacent to the Indian Ocean. B. Seismol. Soc. Am. 56, 1, 69-74.

Burroughs, S. M., Tebbens, S. F., 2005. Power-law scaling and probabilistic forecasting of tsunami runup heights. Pure Appl. Geophys. 162, 331-342.

Byrne, D.E., Sykes, L.R., Davis, D. M., 1992. Great thrust earthquakes and aseismic slip along the plate boundary of the Makran subduction zone. J. Geophys. Res. 97, B1, 449-478.

Carayannis, G. P., 2006. The Potential for Tsunami Generation along the Makran Subduction Zone in the Northern Arabian Sea. Case Study: the Earthquake and Tsunami of November 28, 1945. Sci. Tsunami Hazards 24, 5, 358-384.

Choi, B. H., Pelinovsky, E., Ryabov, I., Hong, S. J., 2002. Distribution functions of tsunami wave heights. Nat. Hazards 25, 1-21.

Dominey-Howes, D., Cummins, P., Burbidge, D., 2006. Historic records of teletsunami in the Indian Ocean and insights from numerical modeling. Nat. Hazards 42, 1,1-17.

Farhoudi, G., Karig, D. E., 1977. The Makran of Iran and Pakistan as an active arc system. Abstr., EOS Trans. Am. Geophys. Union, 58, 446.

Geist, E. L., Parsons, T., 2006. Probabilistic analysis of tsunami hazards. Nat. Hazards 37, 277314.

Goto, C., Ogawa, Y., Shuto, N., Imamura, F., 1997. Numerical Method of Tsunami Simulation with the Leap-Frog Scheme (IUGG/IOC Time Project), IOC Manual, UNESCO, No. 35.

Harvard Seismology, 2007. Global CMT Catalog Search, www.globalcmt.org, Harvard University, Cambridge, Massachusetts, USA

Heck, N.H., 1947. List of seismic sea wave. B. Seismol. Soc. Am. 37, 4, 269-286.

Heidarzadeh, M., Pirooz, M.D., Zaker, N.H., Mokhtari, M., 2006. Tsunami hazard associated with Makran subduction zone along the southern coast of Iran, In: Proceedings of ICOPMAS 2006, the 7th International conference on coastal, ports, and marine structures, Port and Shipping Organization of Iran, 27-29 November 2006, Tehran, Iran.

Heidarzadeh, M., Pirooz, M. D., Zaker, N. H., Yalciner, A. C., Mokhtari, M., 2007-a. Historical tsunamis in the Makran subduction zone off southern coasts of Iran and Pakistan and results of preliminary numerical modeling. Under review in Ocean Eng.

Heidarzadeh, M., Pirooz, M. D., Zaker, N. H., Yalciner, A. C., Mokhtari, M., 2007-b. Assessment of historical tsunamis in the Northwestern Indian Ocean using detailed archival research and hydrodynamic modeling. Under review in Mar. Geol.

International Seismological Centre (ISC), 2007. On-line Bulletin, http://www.isc.ac.uk, Internatl. Seis. Cent., Thatcham, United Kingdom. 
Kijko, A. \& Sellevoll, M.A., 1989. Estimation of earthquake hazard parameters from incomplete data files. Part I: utilization of extreme and complete catalogs with different threshold magnitudes. B. Seismol. Soc. Am. 79, 3, 645-654.

Kijko, A. \& Sellevoll, M.A., 1992. Estimation of earthquake hazard parameters from incomplete data files. Part II: Incorporation of magnitude heterogeneity. B. Seismol. Soc. Am. 82, 1, 120-134.

Koppa, C., Fruehn, J., Flueh, E.R., Reichert, C., Kukowski, N., Bialas, J., Klaeschen, D., 2000. Structure of the Makran subduction zone from wide-angle and reflection seismic data. Tectonophysics 329, 171-191.

Lin, I. C., Tung, C. C., 1982. A preliminary investigation of tsunami hazard. B. Seismol. Soc. Am. 72, 6, 2323-2337.

Merewether, W., 1852. A report of the Disastrous Consequences of the Severe Earthquake Felt in the Provinces of Upper Scinde on the 24th January 1852. J. Bombay Geog. Soc. 10, 284286.

Murty, T., Bapat, A., 1999. Tsunamis on the coastlines of India. Sci. Tsunami Hazards 17, 3, 167-172.

Murty, T., Rafiq, M., 1991. A tentative list of tsunamis in the marginal seas of the north Indian Ocean. Nat. Hazards 4, 81-83.

National Oceanic and Atmospheric Administration (NOAA), 2007. National Geographical Data Center (NGDC). www.ngdc.noaa.gov, NOAA, Washington DC, USA.

Okal, E. A., Fritz, H. M., Raad, P. E., Synolakis, C. E., Al-Shijbi, Y., Al-Saifi, M., 2006. Oman Field Survey after the December 2004 Indian Ocean Tsunami. Earthquake Spectra 22, S3, S203-S218.

Page, W.D., Alt, J.N., Cluff, L.S., Plafker, G., 1979. Evidence for the recurrence of largemagnitude earthquakes along the Makran coast of Iran and Pakistan. Tectonophysics 52, 533-547.

Pendse, C. G., 1946. The Mekran Earthquake of the $28^{\text {th }}$ November 1945. India Meteorol Depart Sci Notes 10 (125), 141-145.

Quittmeyer, R.C., Jacob, K.H., 1979. Historical and modem seismicity of Pakistan, Afghanistan, northwestern India, and southeastern Iran. B. Seismol. Soc. Am. 69, 3, 773823.

Rastogi, B. K., Jaiswal, R. K., 2006. A catalog of tsunamis in the Indian Ocean. Sci. Tsunami Hazards 25, 3, 128-143.

Rikitake, T., Aida, I., 1988. Tsunami hazard probability in Japan. B. Seismol. Soc. Am. 78, 3, 1268-1278.

Schluter, H.U., Prexl, A., Gaedicke, C.H., Roeser, H., Reichert, C.H., Meyer, H., Daniels, C. von., 2002. The Makran accretionary wedge: sediment thicknesses and ages and the origin of mud volcanoes. Mar. Geol. 185, 219-232.

Shearman, D. J., 1977. The geological evolution of southern Iran, the report of the Iranian Makran expedition. Geogr. J. 142, 393-410.

Snead, R.E., 1966. Recent morphological changes along the coast of West Pakistan. Annals of the Association of American Geographers 57, 3, 550-565.

Stoneley, R., 1974. Evolution of the continental margins bounding a former Tethys. In: C. A. Burk and C. L. Drake (Eds), The Geology of Continental Margins, Springer, New York, N. Y., 889-903.

Synolakis, C.E., 2003. Tsunami and Seiche. in Earthquake Engineering Handbook, edited by Chen. W. F., and Scawthorn, C., CRC Press, 9-1-9-90.

Titov, V. V., Synolakis, C. E., 1997. Extreme inundation flow during the Hokkaido-Nansei-Oki tsunami, Geophys. Res. Lett. 24, 1315-1318.

Titov, V.V., Synolakis, C. E., 1998. Numerical Modeling of Tidal Wave Runup. J. Wtrwy. Port. Cost. Eng. B124, 157-171.

US Geological Survey (USGS), 2007. USGS National Earthquake Information Center (NEIC), http://www.usgs.gov, US Geological Survey, Washington DC, USA. 
Vernant, Ph., Nilforoushan, F., Hatzfeld, D., Abbasi, M.R., Vigny, C., Masson, F., Nankali, H., Martinod, J., Ashtiani, A., Bayer, R., Tavakoli, F., Chery, J., 2004. Present-day crustal deformation and plate kinematics in the Middle East constrained by GPS measurements in Iran and northern Oman. Geophys. J. Int. 157, 381-398.

Walker, D. A., 2005. Critical evaluations for the state of Hawaii subsequent to the 26 December 2004 Asian tsunami. Sci. Tsunami Hazards 23, 1, 17-24.

Walton, H.I., 1864. Transactions of the Bombay Geographical Society from January 1863 to December 1864. Education Society‘s Press, Byculla, India.

Yalciner, A. C., Alpar, B., Altinok, Y., Ozbay, I., Imamura, F., 2002. Tsunamis in the Sea of Marmara, Historical Documents for the Past, Models for the Future. Marine Geology 190, 445-463.

Yalciner, A. C., Pelinovsky, E., Talipova, T., Kurkin, A., Kozelkov, A., Zaitsev, A., 2004. Tsunamis in the Black Sea: Comparison of the Historical, Instrumental, and Numerical Data. J. Geophys. Res. 109, 12, 2003-2113.

Yeh, H., Liu, P., Synolakis, C. E., 1996. Long Wave Runup Models. World Scientific Publication Company, London. 403 pp. 